\title{
Soybean Straw, Corn Stover and Sunflower Stalk as Possible Substrates for Biogas Production in Croatia: A Review
}

\author{
Đ. Kovačić, ${ }^{a}$ D. Kralik, ${ }^{a}$ S. Rupčić, ${ }^{b}$ D. Jovičić, ${ }^{a}$ R. Spajić, ${ }^{a}$ and M. Tišma ${ }^{\mathrm{c},}$ \\ a. J. Strossmayer University of Osijek, Faculty of Agriculture in Osijek, \\ Vladimira Preloga 1, 31000 Osijek \\ ${ }^{\mathrm{b} J}$ J. J. Strossmayer University of Osijek, Faculty of Electrical Engineering, \\ Kneza Trpimira 2B, 31000 Osijek \\ 'J. J. Strossmayer University of Osijek, Faculty of Food Technology \\ Osijek, F. Kuhača 20, 31000 Osijek
} doi: 10.15255/CABEQ.2016.985

\begin{abstract}
Biomass availability is one of the key factors for biogas production in the future. The current status and possibilities for utilizing harvest residues (soybean straw, corn stover and sunflower stalk) in Croatia for biogas production is given. In the last few decades, different pretreatment methods have been developed for the degradation of different lignocellulosic biomass, but many of them are environmentally unfriendly and sometimes very expensive. More research and development is necessary in order to find both economically and environmentally friendly pretreatment methods. This paper provides a review on the mechanical, physical, and biological methods used for different lignocellulose material pretreatment. Harvest residues are usually left in the field, but with the improvement of the pretreatment process along with soil protection, they could be used for the production of huge amounts of energy in the future.
\end{abstract}

Key words:

biodegradation, biogas, harvest residues, lignocellulosic biomass, pretreatment

\section{Introduction}

Overall pollution and the need to reduce greenhouse gas emissions, issues related to human and animal health and food safety, the constantly growing trend in fossil fuel consumption and fast-growing economies, are warning signs of an energy and human society crisis. ${ }^{1-3}$ The Kyoto Protocol, the EU Renewables Directive 2001/77/EC, and the European Biomass Action Plan are concerned about these world problems striving to encourage the development of the renewable energy sector and consequently reduce waste production and greenhouse gas emissions as well as increase energy efficiency, which would all lead to a more sustainable future. ${ }^{2}$ With its full EU membership, Croatia is committed to achieve the aforementioned goals, and is therefore obliged to adopt a National Renewable Energy Action Plan. This document states that, in 2020, solid biomass (wood biomass and biomass from agriculture) will play the main role in total renewable energy for the production of thermal energy in Croatia. ${ }^{4}$ As Croatia's import dependence on energy supply increases each year, the utilization of alter-

"Corresponding author: Marina.Tisma@ptfos.hr, phone number: +385 31/224-358, fax number: +385 31/207-115 native energy sources becomes a major issue for future development. Renewable energy technologies have many benefits, like reduced greenhouse gas emissions, decreased fossil fuel use and energy resource diversification. Agricultural biomass exploitation is favorable in the Slavonia and Baranja and Vukovar-Srijem Counties, in the eastern part of Croatia where the highest biomass energy potential is estimated through thorough analysis. ${ }^{5,6}$

Out of Croatia's total area, around $52 \%$ is agricultural land ${ }^{7}$. Agricultural land refers to land that is arable, under permanent crops, or under permanent meadows and pastures. ${ }^{8,9}$ Almost $1 / 3$ of the arable land is under corn, soybean and sunflower production. ${ }^{7}$ Harvested areas and production of corn, soybean and sunflower for a period of 5 years (2010-2014) in Croatia is presented in Table 1. These three crops generate considerable amounts of residues, and are therefore an important source of energy. ${ }^{10}$ It has been estimated that, based on a 10-year-period (2002-2011), 367 million tons of total agricultural residues are annually produced in the EU, whereas 62 million tons is contributed from corn production, 9 million tons from sunflower production, and 2 million tons from soybean production. ${ }^{11}$ If one-third of the residues should remain in 
Table 1 - Harvested area and production of corn, soybean and sunflower in Croatia for a 5-year period

\begin{tabular}{cl|c|c|c|rrr}
\hline & & 2010 & 2011 & 2012 & 2013 & 2014 \\
\hline \multirow{3}{*}{ Corn } & Harvested area (ha) & 296768 & 305130 & 299161 & 288365 & 252567 \\
& Total production (t) & 2067815 & 1733664 & 1297590 & 1874372 & 2046966 \\
\hline \multirow{2}{*}{ Soybean } & Harvested area (ha) & 56456 & 58896 & 54109 & 47156 & 47104 \\
& Total production (t) & 153580 & 147271 & 96718 & 111316 & 131424 \\
\hline \multirow{3}{*}{ Sunflower } & Harvested area (ha) & 26412 & 30041 & 33534 & 40805 & 34869 \\
& Total production (t) & 61789 & 84960 & 90019 & 130576 & 99489 \\
\hline
\end{tabular}

*Source: Croatian Bureau of Statistics, 2015

the field to maintain soil moisture, protect soil carbon, nutrients and soil structure, and to reduce erosion, and one-third is mainly left for other uses like animal feeding and bedding, then around 122 million tons of residues are currently available for bioenergy in the EU. ${ }^{12}$

Considering the possibility of bioenergy production in Croatia (Table 2), the technical potential of corn stover is estimated at 0.37 million tons, soybean straw at 0.02 million tons, and sunflower at 7.8 thousand tons. An average value for a 5-year (2010-2014) production was used for calculating total production based on harvest index. Harvest index is the term used to quantify the yield of a crop species (grain, tuber, or fruit) versus the total amount of biomass that has been produced, and is defined as the ratio of yield to total plant above ground biomass. There is a wide variation in the data because yields and above ground biomass can vary widely from year to year and by soil type. ${ }^{13}$ For this calculation, recommended harvest indices were used for all three plants.

In order to determine the estimation of residues production based on harvest index (marked as A), a 5 -year average production was multiplied by the harvest index value*. Thirty percent of A was assumed to remain in the field for soil protection (data marked as B). Moreover, if the difference between $\mathrm{A}$ and $\mathrm{B}$ is multiplied by 0.3 (assumption that $30 \%$ of residues could be used for technical potential), the amount of residues that could be used as technical potential is obtained (marked as C). The rest is needed for livestock support.

The world production of corn, soybean, and sunflower for the period 2014-2015 was 1009.68, 318.57 , and 39.62 million tons, respectively. ${ }^{14}$ According to the recommended harvest indices, annual residues of corn, soybean and sunflower for that period were determined as $1009.68,318.57$, and 15.85 million tons, respectively.

${ }^{*}$ Calculations are based on the recommended harvest index: for corn 1.0 , soybean 1.0 , and sunflower 0.4 .
Utilization of slurries and manures from pigs, cattle and other domestic animals (resource easily available on many farms) together with the aforementioned agricultural residues, through anaerobic co-digestion creates biogas, a renewable source of energy. ${ }^{15,16}$ Anaerobic co-digestion of agricultural wastes and residues is supposed to be one of the main alternatives in the energy sector because it is considered a complete waste-to-energy transformation. ${ }^{1}$

Biogas plants can be categorized according to the type of digested substrates, according to the technology applied or according to size. In Europe, there are many agricultural biogas plants and they usually co-digest manure and energy-rich co-substrates, like different plant extracts, plants, weeds, crop residues, and ensiled materials that are available naturally in the surroundings. ${ }^{17,18}$ Manure is rich in nitrogen but lacks carbon, so using manure alone may not represent the most efficient way to produce biogas. Therefore, a high carbon content plant material is usually added as co-substrate to improve the $\mathrm{C} / \mathrm{N}$ ratio and decrease the risk of ammonia inhibition. ${ }^{19,20}$ Common plant materials which are mostly used in European biogas plants are crops and silages, and they present first generation biogas.

However, crops are the most important source of food and feed in the world, and the food demand

Table 2 -Average production of corn, soybean and sunflower in Croatia for a 5-year period (2010-2014) and average technical potential of their residues

\begin{tabular}{|c|c|c|c|}
\hline & Corn & Soybean & Sunflower \\
\hline 5-year-average production $(\mathrm{t})$ & 1804.081 & 128.061 & 93.366 \\
\hline $\begin{array}{l}\text { Estimate of residues production } \\
\text { based on harvest index (t) A }\end{array}$ & 1804.081 & 128.061 & 37.346 \\
\hline $\begin{array}{l}30 \% \text { of residues needed for soil } \\
\text { protection }(\mathrm{t}) \mathrm{B}\end{array}$ & 541.224 & 38.418 & 11.204 \\
\hline $\begin{array}{l}30 \% \text { of residues for technical } \\
\text { potential }(\mathrm{t}) \mathrm{C}\end{array}$ & 378.857 & 26.893 & 7.843 \\
\hline
\end{tabular}


is expected to increase in the future. Additionally, using crops as feedstock for biofuels production may have a huge impact on biodiversity and land use, but the main problem is the food vs. fuel controversy. As a replacement, one way to avoid the negative effects of producing biofuels from food supplies is to use lignocellulosic biomass. In other words, second-generation feedstocks should be favored. These second-generation feedstocks are lignocellulosic agro-industrial byproducts which have no market and are destined for landfills or remain in the fields after harvesting. However, current technologies for processing these feedstocks are not cost effective and are still being developed, because there are a number of technical barriers that need to be overcome. ${ }^{21,22}$

Currently, there are 13 biogas plants in Croatia (according to the Croatian Chamber of Economy report of March $2015^{23}$ ), and 10 of them are using agricultural feedstock (mostly manures as the base substrate, and silage as the co-substrate) in the process. None of them co-digests harvest residues like straws and stovers.

According to the European Biogas Association's $(\text { EBA })^{24}$ Biogas Report 2016, there were 17376 biogas plants in Europe by late 2015. Most of them are producing biogas from agricultural feedstock like energy crops, agricultural residues, catch crops, and animal manure. Usually, this is performed by anaerobic co-digestion of animal manure and agricultural feedstock. Only a few biogas plants are producing biogas using harvest residues..$^{25}$ The potential from agriculture is still largely unexplored and unexploited, and this sector is expected to have huge growth rates in the coming years. ${ }^{26}$

The objective of this paper was to provide a) an overview of the annual production of corn, soybean, and sunflower, and their harvest residues in the world and in Croatia; b) information on lignocellulose-rich material chemical composition, and c) an overview of different environmentally friendly pretreatment methods for bioconversion of harvest residues in order to achieve higher biogas yields via anaerobic digestion (AD).

\section{Agricultural lignocellulosic biomass}

The term "lignocellulosic biomass" refers to higher plants, softwood or hardwood. The composition of agricultural lignocellulosic biomass depends on its source, but typically is comprised of about 40-50\% cellulose, 20-30\% hemicellulose, and $10-25 \%$ lignin. $^{27,28}$

Cellulose is the main component of lignocellulose cell walls, which gives a plant hardness and chemical stability. It is a linear polysaccharide polymer made of long chains of cellobiose units linked via $\beta-1,4$ glycosidic linkages. In the cellulose chains, a number of hydroxylic groups are presented leading to the formation of hydrogen bonds, while cellulose chains are interlinked by hydrogen bonds and van der Waals forces. Because of different orientations throughout the structure, cellulose molecules have different levels of crystallinity low crystallinity (amorphous regions), and high crystallinity (crystalline regions). ${ }^{29}$ The crystalline form prevails in the major part of the cellulose and is hardly hydrolyzed in comparison to amorphous form. It is therefore expected that high-crystallinity cellulose will be more resistant to enzymatic hydrolysis, but reduction of crystallinity will increase the degradability. ${ }^{30}$

Hemicellulose is a term used to represent a family of polysaccharides, such as pentoses (xylose and arabinose), hexoses (glucose, galactose, mannose and/or rhamnose), and acids (glucuronic acid, methyl glucuronic acid, and galacturonic acid). ${ }^{27,29,31}$ The dominant component of hemicelluloses from hardwood and agricultural plants is xylan, while in softwoods glucomanan dominates. Hemicelluloses have a lower molecular weight than cellulose and are more amorphous, random, and branched with little strength that makes it highly susceptible to biological, thermal, and chemical hydrolysis. ${ }^{29,32}$

Lignin is the most complex polymer in nature. ${ }^{27}$ It is a large and complex aromatic and hydrophobic amorphous heteropolymer consisting of three different phenylpropane alcohols: $p$-coumaryl, coniferyl and sinapyl, and their quantity varies according to species, maturity, and the space localization in the cell. Lignin gives the plant a structural rigidity, impermeability, and resistance against microbial attacks and oxidative stress. It is insoluble in water and optically inert, and therefore very difficult to degrade. The higher the lignin content, the greater is the resistance of the biomass to degradation. Lignin is a major barrier in the lignocellulosic biomass bioconversion process. ${ }^{29,32}$

Harvest residues could be a good source for $\mathrm{AD}$, due to large availability of biomass. However, agricultural biomass like sunflower stalk, corn stover, and soybean straw contain complex structure of lignocellulose, and does not contain easily fermentable free sugars (Table 3). Therefore, its biotransformation to biofuels cannot be easily conducted. ${ }^{33-36}$

However, these lignocellulosic biomasses contain soluble, fermentable sugars (Table 4), natural intermediates in conversion to biofuels, but access to sugars is hindered by the recalcitrance of plant cell walls. Therefore, deriving sugars from this material requires mechanical, physical or chemical disruption. ${ }^{51}$ 
Table 3 -Chemical composition of lignocellulosic biomass

\begin{tabular}{c|c|c|c}
\hline $\begin{array}{c}\text { Lignocellulosic } \\
\text { biomass }\end{array}$ & Parameter & Content (\%) & References \\
\hline & Total solids & $94-96$ & 36,37 \\
& Volatile solids & $88-89$ & 36,37 \\
Sunflower stalk & Cellulose & $34-42$ & $37-40$ \\
& Hemicellulose & $19-33$ & $37-40$ \\
& Klason lignin & $12-30$ & $34,37,38,40$ \\
\hline \multirow{4}{*}{ Corn stover } & Total solids & $94-97$ & 41,42 \\
& Volatile solids & $88-92$ & 41,42 \\
& Cellulose & $31-41$ & $32,40,41,43-45$ \\
& Hemicellulose & $19-34$ & $32,40,41,43-45$ \\
& Klason lignin & $14-18$ & $40,41,45$ \\
\hline \multirow{5}{*}{ Soybean straw } & Total solids & $87-88$ & 46,47 \\
& Volatile solids & 91 & 48 \\
& Cellulose & $25-49$ & 49,50 \\
& Hemicellulose & $12-29$ & 49,50 \\
& Klason lignin & 18 & 50 \\
\hline
\end{tabular}

*All values are shown on a total solids basis (expect TS)

\section{Pretreatments of lignocellulosic biomass as a crucial step in biogas production}

Pretreatment is a crucial process step for the bioconversion of lignocellulosic biomass into biofuels. There are a number of different pretreatment technologies developed, but there are also technical barriers that make them expensive. ${ }^{27}$ Pretreatment methods should be economically and practically viable ${ }^{57}$, should improve the formation and avoid the loss or degradation of carbohydrates, avoid the formation of byproducts that are inhibitory to the hydrolysis and fermentation processes, and avoid consumption of chemicals. ${ }^{58}$

The goal of the pretreatment process is to: (a) increase the surface area and porosity of the biomass, (b) alter lignin structure, (c) depolymerize hemicellulose, (d) remove lignin, and (e) reduce the crystallinity of cellulose. ${ }^{27,58}$

Pretreatment methods can be divided into different categories: mechanical, physical, chemical, biological and various combinations of these. ${ }^{27,29,32}$
Further in the text, the most common pretreatment methods used for corn, soybean and sunflower harvest residues (or the residues similar to them according to the chemical composition) are discussed in more detail. To our knowledge, the AD of soybean straw and sunflower stalk has not been studied in detail so far. Therefore, there is not much information on their degradability and possibility of utilization for biogas production. Generally, only a few authors have conducted research on these feedstocks regarding biofuels production. In contrast, there is much more research conducted using corn stover. Pretreatments that are quite expensive and aggressive to nature have mostly been studied so far. The aim of this paper was to present pretreatment methods that do not apply aggressive chemicals and agents, and are not harmful to nature, as well as to emphasize the need for their further development and improvement.

\section{Mechanical pretreatment}

Mechanical pretreatment is considered one of the most expensive processing steps in lignocellulose biomass conversion. However, it is also a crucial step which greatly contributes to the increase in hydrolysis efficiency and consequently higher biogas yields ${ }^{59,60}$ It could be carried out easily by mills or shredders in every agro-biogas plant. ${ }^{61}$

The energy requirements of mechanical pretreatment depend on the type of the mill, initial and final particle sizes, material characteristics (amount, composition and moisture content). ${ }^{62}$ The choice of the right comminution device depends particularly on the moisture content in the material ${ }^{60}$ Colloid mills and extruders are suitable for comminuting of wet materials with moisture contents of more than 15-20\% (wet basis), while different milling devices (hammer mills, knife mills, two-roll mills, attrition mills) are suitable for comminuting of dry materials with moisture contents of up to 10-15\% (wet basis). The ball or vibratory ball mills, as universal types of comminuting devices, can be used for either dry or wet materials. ${ }^{30}$

Chipping, milling or grinding lead to the reduction of the particle size increasing the accessible surface area, reducing the degree of cellulose crystallinity and the degree of cellulose and hemicellu-

Table 4 -Polysaccharides composition in corn, soybean and sunflower harvest residues

\begin{tabular}{c|c|c|c|c|c|c}
\hline Agricultural residue & Glucan (\%) & Xylan (\%) & Arabinan (\%) & Galactan (\%) & Mannan (\%) & References \\
\hline Corn stover & $26.5-40.9$ & $14.8-25.8$ & $1.6-6.1$ & $0.7-3.0$ & $0-1.8$ & $32,44,45,52,53$ \\
Soybean straw & 34.09 & 11.4 & 1.0 & 1.8 & 1.8 & 54 \\
Sunflower stalk & $31.5-39.0$ & $14.8-24.4$ & $0.66-3.1$ & $1.3-2.0$ & - & $34,55,56$ \\
\hline
\end{tabular}

*All values are shown on a total solids basis 
loses polymerization..$^{29,32}$ By breaking the large structures, the efficiency of the hydrolysis increases. ${ }^{59}$ It is well documented that smaller particles are better digested in biogas production particularly if combined with some other pretreatment method. ${ }^{30}$ Sharma et $a l .{ }^{43}$ conducted experiments with different particle sizes $(0.088,0.40,1,6$ and $30 \mathrm{~mm})$ of forest and agricultural residues, and found that the highest biogas yield was obtained using the smallest substrate particles $(0.088$ and $0.40 \mathrm{~mm})$. Zheng et $a l .{ }^{64}$ examined different particle sizes of corn stover and concluded that smaller particles $(53-75 \mu \mathrm{m})$ are more susceptible to hydrolysis than larger particles $(425-710 \mu \mathrm{m})$. Xiao et al. ${ }^{65}$ obtained higher methane yields by reducing particle sizes of alkaline pretreated corn stover from 5-20 $\mathrm{mm}$ to $0.075-5 \mathrm{~mm}$. In their pilot-scale experiment, Schell and Harwood $^{66}$ showed that lignocellulose particle size of 1 to $2 \mathrm{~mm}$ is effective for hydrolysis. Menardo et al. ${ }^{67}$ conducted various mechanical and thermal treatments prior to $\mathrm{AD}$ of four agricultural byproducts. An net electrical energy balance was also completed to analyze the feasibility of the pretreatments according to energy input and output. Mechanical treatment included particle size reduction to 5.0, $2.0,0.5$, and $0.2 \mathrm{~cm}$, whereas size reduction to 0.5 resulted in the increase in methane yield and electrical energy balance. Mshandete et al. ${ }^{68}$ investigated the effect of sisal fibre particle size reduction on biogas production. The sisal fibres were reduced to $2,5,10,30,50,70$ and $100 \mathrm{~mm}$ particle size and anaerobically digested in mesophilic batch reactors with sisal wastewater sludge used as inoculum during 65 days. The results showed that the methane yield was inversely proportional to particle size, with respect to a best result obtained from $2 \mathrm{~mm}$ particle size which resulted in $23 \%$ higher methane yield $\left(0.22 \mathrm{~m}^{3} \mathrm{~kg}^{-1} \mathrm{VS}\right)$ compared to untreated sisal fibres $\left(0.18 \mathrm{~m}^{3} \mathrm{~kg}^{-1} \mathrm{VS}\right)$. Liu et al. ${ }^{69}$ conducted steam explosion pretreatment of corn stover with particle sizes at 2.5, 2.0, 1.5, 1.0, and $0.5 \mathrm{~cm}$ in order to improve its enzymatic digestibility. The results showed a higher amount of byproducts and lower sugar recoveries for the larger biomass particles $(2.5 \mathrm{~cm})$ during pretreatment, while sugar conversions and yields were higher during enzymatic hydrolysis. According to these results, larger corn stover particles would be more suitable for steam explosion pretreatment, reducing process costs at the same time.

\section{Physical pretreatment}

There are many different methods that are classified in this group, like steam explosion, hydrothermolysis, extrusion, and irradiation..$^{29,30}$ According to Mtui, ${ }^{70}$ temperature and irradiation are the most successful physical treatments used in the processing of lignocellulosic biomass.

In the process of steam explosion or autohydrolysis, the lignocellulosic material is heated to high temperatures $\left(160-260{ }^{\circ} \mathrm{C}\right)$ with high-pressure saturated steam $(0.69$ to $4.83 \mathrm{MPa})$ for a short time (a few seconds to a few minutes), and then the pressure is promptly reduced to complete the reaction, which causes the material to explode. This method is one of the most common pretreatment methods for lignocellulosic material and is commercially available. ${ }^{29}$ Sunflower stalks were subjected to steam explosion pretreatment, in order to optimize pretreatment temperature in the range $180-230{ }^{\circ} \mathrm{C}$, accompanied by enzymatic hydrolysis. The highest glucose yield was obtained at $220{ }^{\circ} \mathrm{C}$, while the highest hemicellulose recovery was obtained at 210 ${ }^{\circ} \mathrm{C} .{ }^{39}$ Bondesson et al. ${ }^{71}$ pretreated corn stover using steam explosion with and without addition of sulphuric acid as catalyst, and examined the effect of residence time and temperature on glucose and xylose recovery. The highest glucose yield was achieved after pretreatment at $210{ }^{\circ} \mathrm{C}$ for $10 \mathrm{~min}$ without the addition of catalyst and followed by enzymatic hydrolysis. The highest yield with the addition of catalyst was achieved at $200{ }^{\circ} \mathrm{C}$ for $10 \mathrm{~min}$. The highest methane yield was obtained from the material pretreated with acid.

Hydrothermolysis or pretreatment in liquid hot water and high pressure is highly effective for enlarging the accessible surface area of cellulose, for improvement of cellulose degradability and for enhancement of sugar extraction. ${ }^{29}$ Mosier et al. ${ }^{72}$ pretreated corn stover in liquid hot water and reported optimal conditions at $190{ }^{\circ} \mathrm{C}$ and $15 \mathrm{~min}$, in which $90 \%$ of cellulose was converted by subsequent enzymatic hydrolysis. Chandra et $a l^{73}$ pretreated wheat straw using hydrothermolysis which resulted in $9.2 \%$ higher biogas yield and $20 \%$ higher methane yield compared to untreated wheat straw substrate.

Extrusion is a process that combines multiple operations, like high shear, temperature (60 to 300 ${ }^{\circ} \mathrm{C}$ ), and pressure (up to $30 \mathrm{MPa}$ ). ${ }^{29,74}$ Extrusion causes depolymerization of cellulose, hemicellulose, lignin, and protein, and sometimes also thermal degradation of sugars and amino acids. Hjorth et $a .^{75}$ tested five agricultural biomasses (straw, fresh grass, solid fraction of manure, and deep litter from cattle) for the biogas production by using extrusion as pretreatment. Extrusion accelerated the degradation of the majority of organic compounds which in turn increased methane yield by $18-70 \%$ after 28 days of $\mathrm{AD}$, and $9-28 \%$ after 90 days of AD. The rate of biogas production from extruded materials was faster in comparison to untreated materials, especially when straw was used. 
Irradiation includes ultrasound, microwaves, gamma-rays, electron beam, and electrokinetic disintegration. ${ }^{29,30,74}$ Like in all other methods, when applying irradiation it is important to prevent the formation of inhibitors (e.g. phenolic compounds and furfural) by choosing the optimal process conditions. $^{29}$

Microwave technology is the most studied irradiation pretreatment method. ${ }^{29}$ It is effective in reducing the lignin ratio and the proportion of cellulose and hemicellulose, but usually combined with some chemical which is not favored. ${ }^{76-78}$ Deepanraj et al. ${ }^{59}$ suggested autoclave and microwave methods rather than thermal pretreatment of biomass material.

Ultrasound pretreatment disrupts cell wall structure and reduces the degree of polymerization. There is evidence that this pretreatment method cannot disintegrate lignocellulosic material, but it can improve accessibility to cellulose. It is usually used for pretreatment of water, industrial wastewater, sludge, manure, and different liquid effluents. ${ }^{74,79}$ Liqian $^{80}$ compared the performance of different pretreatment methods (thermal, chemical and ultrasound) on agricultural biomasses. Ultrasound had a positive effect on the methane yield (increase up to $40 \%$ ) but considering the high energy input, it was stated as not profitable pretreatment.

Electric field or electroporation is used for a variety of processes in modern biotechnology but still has not been extensively studied, and the effect on lignocellulose is still not completely explained. ${ }^{74}$ According to Kumar et al. ${ }^{58}$ pulsed electric field can affect the structural changes in plant tissue increasing the mass permeability and mechanical rupture of the plant tissue. This method is currently of interest to the food industry. ${ }^{81}$ It is used for diffusion of soluble substances, juice extraction, and dehydration. ${ }^{82-85}$ In biogas production high electric field strengths in the range of $5-20 \mathrm{kV} \mathrm{cm}^{-1}$ are used, causing the rupture of cells and creating pores in the cell membrane, making intracellular content available for fermentation. Electroporation also facilitates the entry of enzymes in the cell, causing the breakdown of cellulose and hemicellulose into their constituent sugars which are fermentable. Lindmark ${ }^{86}$ studied the influence of electroporation on lay crop silage for biogas production and concluded that it holds the greatest potential for improving the efficiency of a biogas plant.

\section{Biological pretreatment}

Biological pretreatments mainly include fungal pretreatment, pretreatment by microbial consortium, and enzymatic pretreatment. The most commonly used microorganisms are white, brown, and soft-rot fungi, but actinomycetes and bacteria can be used for this purpose as well. Biological methods require low energy input and are performed under mild process conditions. However, the reaction rate of polymer hydrolysis using biological methods are usually very low and those methods require strict control of microorganism growth conditions, which limits their application for commercial purposes. ${ }^{27,29,87,88}$

Wood-rotting fungi that are commonly found in nature are among a number of organisms that can degrade lignocellulose components to various extents, and are generally grouped into soft-rot, brown-rot, and white-rot fungi. ${ }^{89}$ White-rot fungi can degrade and mineralize all three major wood polymers: cellulose, hemicellulose, and lignin, whereas lignin can be degraded extensively resulting in a bleached appearance of degraded wood. ${ }^{90}$ This ability is due to the fact that white-rot fungi produce a variety of enzymes, such as lignin peroxidases, manganese-dependent peroxidases, and laccases that degrade the lignin. ${ }^{91}$ Planinić et al. ${ }^{92}$ treated lignocellulose waste from the agro-, food and wood industries for 7 days with $T$. versicolor, which resulted in lignin conversion up to $71 \%$. Tišma et al. ${ }^{93}$ studied Trametes versicolor growth on glucose, fructose, and sucrose, and developed a mathematical model of the process composed of sucrose hydrolysis catalyzed by intracellular enzyme, and microbial growth on glucose and fructose. Tišma et $a l .{ }^{94}$ used diverse media (industrial waste) for $T$. versicolor MZKI G-99 submerged cultivation with the aim of enzyme laccase production. Waste from the paper industry showed the highest potential for laccase production. It was proved a safe and inexpensive substrate for commercial production of laccase. However, fungal degradation of lignocellulose waste so far has not been an approach of commercial significance. Phutela et al. ${ }^{95}$ pretreated paddy straw using Trichoderma reseei MTCC 164 and Coriolus versicolor MTCC 138 at different time intervals, and then anaerobically digested straw. Paddy straw pretreated with $T$. reesei showed $20.8 \%$ enhanced biogas production, while straw treated with C. versicolor showed $26.2 \%$ enhanced biogas production with a maximum of $19.1 \%$ reduction in lignin. Liu et al. ${ }^{96}$ pretreated corn stover silage by Phanerochaete chrysosporium in solid-state fermentation to enhance methane production via $\mathrm{AD}$. It was found that $P$. chrysosporium degraded cellulose, hemicellulose, and lignin up to $19.9,32.4$, and $22.6 \%$, respectively. Consequently, pretreated corn stover silage achieved up to $23 \%$ higher methane yield than the untreated corn stover silage. Liu et al. ${ }^{97}$ pretreated yellow corn stover and corn stover silage with white-rot fungi to enhance biogas production. The pretreatment of yellow corn stover was accompanied by $38.3 \%$ cellulose, $42.2 \%$ hemicellulose, and $39.1 \%$ lignin degradation, while the 
pretreatment of corn stover silage was accompanied by $9.9 \%$ cellulose, $23.2 \%$ hemicellulose, and $15.2 \%$ lignin degradation. The reducing sugar yield of pretreated corn stover and corn stover silage after enzymatic hydrolysis was $195.8 \mathrm{mg} \mathrm{g}^{-1}$ and $67.7 \mathrm{mg} \mathrm{g}^{-1}$, respectively, which indicated that much more corn stover was degraded in comparison to pretreated corn stover silage. The results also showed $29.2 \%$ higher methane production of pretreated corn stover silage after 21 days of $\mathrm{AD}$ in comparison to untreated corn stover silage, and $73.1 \%$ higher methane production after 60 days of digestion. Higher biogas yield of pretreated corn stover was not achieved. Some other lignocellulosic biomass like wheat straw $^{98-100}$, Japanese cedar wood ${ }^{101}$, and rice straw ${ }^{102,103}$, have also been successfully degraded using whiterot fungi, which ultimately affected the increase in the production of biogas.

Microbial consortium consists of microbes screened from natural environments in which rotten lignocellulosic material is the substrate. In contrast to fungal pretreatment, which is mainly applied for lignin degradation, a microbial consortium usually has high ability to degrade cellulose and hemicellulose. ${ }^{29}$ Kangrang et al. ${ }^{104}$ investigated the effect of microbial consortia obtained from cattle and horse manure, and decomposed wood for production of cellulase, and further enhancement of biogas production from rice straw. To select the most efficient consortium, cellulase enzymes were extracted and

Table 5 -Literature review of research for corn stover pretreatment methods

\begin{tabular}{|c|c|c|c|c|}
\hline $\begin{array}{l}\text { Pretreatment } \\
\text { method }\end{array}$ & Process & Pretreatment conditions & Results & References \\
\hline \multirow{3}{*}{ Mechanical } & $\begin{array}{l}\text { Size reduction } \\
\text { (knife mill) }\end{array}$ & Particle size: $0.5-2.5 \mathrm{~cm}$ & $\begin{array}{c}\text { Up to } 100 \% \text { glucan recovery, and } 83 \% \\
\text { xylan recovery }\end{array}$ & 109 \\
\hline & $\begin{array}{l}\text { Size reduction } \\
\text { (scissors, food } \\
\text { mixer-cutter and } \\
\text { knife mill) }\end{array}$ & Particle size: $0.2-5.0 \mathrm{~cm}$ & $\begin{array}{l}\text { Reduced organic matter degradation time; } \\
\text { no significant improvement in methane } \\
\text { production (up to } 272 \mathrm{dm}_{\mathrm{N}}^{3} \mathrm{~kg}^{-1} \mathrm{VS} \text { ) }\end{array}$ & 67 \\
\hline & $\begin{array}{l}\text { Size reduction } \\
\quad \text { (grinder) }\end{array}$ & Particle size: $2-20 \mathrm{~mm}$ & $\begin{array}{c}\text { Decrease in the organic solid content by } \\
\text { nearly } 80 \% \text {, up to four-fold reduction in } \\
\text { total solids after AD }\end{array}$ & 110 \\
\hline \multirow{2}{*}{ Physical } & Thermal treatment & $\begin{array}{c}\text { Autoclave, } T=90 \text { and } 120^{\circ} \mathrm{C} \\
t=30 \mathrm{~min}\end{array}$ & $\begin{array}{l}\text { No significant improvement in the methane } \\
\text { yields (up to } 267 \mathrm{dm}^{3}{ }_{\mathrm{N}} \mathrm{kg}^{-1} \mathrm{VS} \text { ) }\end{array}$ & 67 \\
\hline & Thermal treatment & $\begin{array}{l}\text { Fluidized bed-pyrolysis reactor, } \\
T=180,200 \text { and } 220^{\circ} \mathrm{C}, t=1 \mathrm{~s}\end{array}$ & $\begin{array}{l}\text { Up to } 33 \% \text { reduction in lignin; } 10 \% \\
\text { improvement in biogas yield }\end{array}$ & 111 \\
\hline \multirow{6}{*}{ Biological } & Fungal treatment & $\begin{array}{l}\text { Pleurotus ostreatus and Trametes } \\
\text { versicolor; inoculated in sterile } \\
\text { polypropylene bags with membrane } \\
\text { that permitted gas exchange, } \\
\quad T=20^{\circ} \mathrm{C}, t=1-4 \text { months }\end{array}$ & $\begin{array}{c}\text { Changes in chemical composition of corn } \\
\text { stover were not beneficial to the feed value } \\
\text { of the crop and resulted in high losses of } \\
\text { dry matter }\end{array}$ & 112 \\
\hline & Enzymatic treatment & $\begin{array}{c}\text { Commercial cellulase }- \text { Accellerase } \\
\text { 1500, and Novozyme } 188 \\
T=50^{\circ} \mathrm{C}, t=168 \mathrm{~h}\end{array}$ & $\begin{array}{l}\text { Enzymatic hydrolysis was conducted after } \\
\text { mechanical pretreatment and subsequent } \\
\text { steam explosion; up to } 99 \% \text { glucan } \\
\text { conversion, and up to } 82 \% \text { xylan } \\
\text { conversion; lignin recovery around } 75 \%\end{array}$ & 109 \\
\hline & Enzymatic treatment & $\begin{array}{l}\text { Cellulase (Spezyme CP) and } \\
\text { Multifect xylanase; } 1-\mathrm{dm}^{3} \text { glass } \\
\text { reactors in walk-in incubation room, } \\
T=37 \pm 1^{\circ} \mathrm{C}, t=30 \text { days }\end{array}$ & $\begin{array}{l}\text { Around } 37 \% \text { cellulose removal, and } 30 \% \\
\text { hemicellulose removal; up to } 135 \mathrm{dm}^{3} \mathrm{~kg}^{-1} \\
\text { VS of total methane yield }\end{array}$ & 113 \\
\hline & Fungal treatment & $\begin{array}{c}\text { Flasks, Phanerochaete } \\
\text { chrysosporium; } T=28{ }^{\circ} \mathrm{C}, \\
t=30 \text { days }\end{array}$ & $\begin{array}{l}55 \% \text { degradation of cellulose, } 64 \% \text { of } \\
\text { hemicellulose, and } 61 \% \text { of lignin; no } \\
\text { significant influence on biogas production }\end{array}$ & 114 \\
\hline & Enzymatic treatment & $\begin{array}{l}\text { NS81210 cellulase complex and } \\
\text { NS81220 protease }\end{array}$ & $\begin{array}{c}\text { Up to } 11 \% \text { higher biogas yield; up to } 9 \% \\
\text { higher methane yield }\end{array}$ & 115 \\
\hline & Enzymatic treatment & $\begin{array}{l}\text { Laccase, manganese peroxidase, } \\
\text { and versatile peroxidase; anaerobic } \\
\text { air-tight batch reactors, } \\
\qquad \begin{array}{c}V=250 \mathrm{dm}^{3}, T=30^{\circ} \mathrm{C} \\
t=6 \text { and } 24 \mathrm{~h}\end{array}\end{array}$ & $\begin{array}{l}\text { No evidence of inhibitors, high yield; } \\
\text { laccase increased methane yield by } 25 \% \text {, } \\
\text { and peroxidase increased methane yield by } \\
17 \% \text {; no sinergy between enzymes } \\
\text { detected; up to } 16 \% \text { increased methane } \\
\text { yield after treatment with both enzymes }\end{array}$ & 116 \\
\hline
\end{tabular}


their activities were analyzed. The results suggested that microbial consortium obtained from cattle manure is the best candidate for biogas production, and the highest cumulative biogas yield was $104.6 \mathrm{dm}^{3} \mathrm{~g}^{-1}$. Yan et al. ${ }^{105}$ cultivated mesophilic lignocellulolytic microbial consortium BYND-5 and applied it to enhance the biogas production from rice straw. The results showed degradation efficiency of BYND-5 for rice straw of more than $49 \%$ after 7 days of cultivation at $30^{\circ} \mathrm{C}$.

Enzymatic pretreatment is applied prior to or in the $\mathrm{AD}$ of biomass in order to increase biogas production. These are cellulases and hemicellulases, hydrolytic enzymes, which are too expensive, and enhancement in biogas production is minimal. Therefore, their application in AD is limited. ${ }^{29}$ Spajić $^{106}$ in his doctoral research, tested different substrates from agriculture and food industry (pig manure as base substrate, and cheese whey, brewery yeast, slaughter waste and corn silage as co-substrates) for biogas potential. Before anaerobic co-digestion, ultrasound and enzymatic pretreatments (using enzyme Spezyme CP) were conducted on all samples. After ultrasound pretreatment and subsequent anaerobic codigestion, up to $34 \%$ higher methane yield was achieved, whereas enzymatic hydrolysis did not have effect on methane yield increase. Boussaid and Saddler ${ }^{107}$ showed that higher enzyme loadings are needed for lignin substrates as the adsorption of enzymes to lignin is more difficult, and when using commercial enzyme mixtures because of the lower specific enzyme activity. Therefore, Gao et al. ${ }^{108}$ conducted the "in-house" developed enzyme cocktail optimization for degradation of corn stover, instead of using expensive commercial enzymes. The results showed high glucose (around $80 \%$ ) and xylose (around $70 \%$ ) yields with moderate enzyme loading ( $\sim 20 \mathrm{mg}$ protein $\mathrm{g}^{-1}$ glucan).

As mentioned previously, there is limited literature information available on the soybean straw and sunflower stalk usage in biogas production. The results on corn stover degradation, using different pretreatment methods, with the aim of its further application in biogas production, are presented in Table 5.

\section{Conclusion}

Biogas is a renewable energy source the production of which depends on availability and type of biomass. By using biomass for energy production, productive land is destined to supply energy, not food or feed, which could have a huge impact on biodiversity and land use. However, the main problem is the food vs. fuel controversy. Therefore, utilization of crops for biogas production should be substituted with lignocellulosic residual biomass, which originates after harvest or crops processing. These byproducts have no market and are destined for landfills or remain in the fields after harvesting. Their chemical structure is complex and hard to degrade, which represents a challenge. Therefore, the pretreatment step of lignocellulosic biomass is crucial in their usage for biogas production. However, the pretreatment step is considered as rate-limiting step and governs the final cost of products.

Croatia recognizes the biogas potential but it is still poorly utilized compared to other EU states. Regarding lignocellulosic residues potential, especially of these three crops (corn, soybean and sunflower) that are of huge importance for Croatia, the situation is promising. However, methods that are used as pretreatment of lignocellulosic biomass are still too expensive and not cost-effective. They are still under development and the goal is to find technologies that protect and care for the environment and are not expensive. The point is not to produce as much energy as possible by any means, but to produce energy in a sustainable manner that will benefit all.

\section{ACKNOWLEDGEMENTS}

This work was financially supported by the project "ProBioTech - Development of innovative process of agricultural waste biological treatment in biogas production" (RC. 2.2.08-0045), which was co-financed by European Regional Development Fund (ERDF).

\section{List of symbols}

$$
\begin{aligned}
& \mathrm{AD}-\text { anaerobic digestion } \\
& \mathrm{VS}-\text { volatile solids } \\
& T-\text { temperature, }{ }^{\circ} \mathrm{C} \\
& t \quad-\text { time, } \text { min } \\
& V \quad-\text { volume, } \mathrm{dm}^{3}
\end{aligned}
$$

\section{References}

1. Cavinato, C., Fatone, F., Bolzonella, D., Pavan, P., Thermophilic anaerobic co-digestion of cattle manure with agro-wastes and energy crops: Comparison of pilot and full scale experiences, Bioresour. Technol. 101 (2010) 545. doi: https://doi.org/10.1016/j.biortech.2009.08.043

2. Panwar, N. L., Kaushik, S. C., Kothari S., Role of renewable energy sources in environmental protection: A review, Renew. Sust. Energ. Rev. 15 (2011) 1513. doi: https://doi.org/10.1016/j.rser.2010.11.037

3. Gupta, A., Kumar, A., Sharma, S., Vijay, V. K., Comparative evaluation of raw and detoxified mahua seed cake for biogas production, Appl. Energ. 102 (2013) 1514. doi: https://doi.org/10.1016/j.apenergy.2012.09.017 
4. URL: https://ec.europa.eu/energy/en/topics/renewable-energy/national-action-plans (19.3.2016)

5. Schneider, D. R., Duić, N., Bogdan, Ž., Mapping the potential for decentralized energy generation based on renewable energy sources in the Republic of Croatia, Energy 32 (2007) 1731. doi: https://doi.org/10.1016/j.energy.2006.12.003

6. Cosić, B., Stanić, Z., Duić, N., Geographic distribution of economic potential of agricultural and forest biomass residual for energy use: Case study Croatia, Energy 36 (2011) 2017.

doi: https://doi.org/10.1016/j.energy.2010.10.009

7. URL: http://www.dzs.hr (19.3.2016.)

8. Agricultural Land Act, Official Gazette 39/13, 48/15.

9. URL: https://stats.oecd.org/glossary/detail.asp?ID $=74$ (24. 3. 2017)

10. URL: http://www.fao.org/agriculture/crops/thematicsitemap/theme/seedspgr/sow/sow2/country-reports/en/ (22. 3. 2016)

11. URL: http://www.theicct.org/availability-cellulosic-residues-and-wastes-eu (22. 3. 2016)

12. URL: http://theicct.org/wasted-europes-untapped-resource-report (22. 3. 2016)

13. URL: http://msue.anr.msu.edu/news/harvest index a predictor_of_corn_stover_yield (24.3.2017).

14. URL: http://usda.mannlib.cornell.edu/MannUsda/viewDocumentInfo.do?documentID=1860 (22. 3. 2016)

15. Kulišić, B., Par, V., Agricultural potential for biogas production in Croatia, Agric. Conspec. Sci. 74 (3) (2009) 215.

16. Kralik, G., Adámek, Z., Baban, M., Bogut, I., Gantner, V., Ivanković, S., Katavić, I., Kralik, D., Kralik, I., Margeta, V., Pavličević, J., Zootehnika, Grafika, Osijek, 2011, pp 567.

17. Holm-Nielsen, J. B., Al Seadi, T., Oleskowicz-Popiel, P., The future of anaerobic digestion and biogas utilization, Bioresour. Technol. 100 (2009) 5478. doi: https://doi.org/10.1016/j.biortech.2008.12.046

18. Mao, C., Feng, Y., Wang, X., Ren, G., Review on research achievements of biogas from anaerobic digestion, Renew. Sust. Energ. Rev. 45 (2015) 540. doi: https://doi.org/10.1016/j.rser.2015.02.032

19. Wu, X., Yao, W., Zhu, J., Miller, C., Biogas and $\mathrm{CH}_{4}$ productivity by co-digesting swine manure with three crop residues as an external carbon source, Bioresour. Technol. 101 (2010) 4042 . doi: https://doi.org/10.1016/j.biortech.2010.01.052

20. Belostotskiy, D., Jacobi, H. F., Strach, K., Liebetrau, J. Anaerobic digestion of chicken manure as a single substrate by control of ammonia concentration, In: $13^{\text {th }}$ World Congress on Anaerobic Digestion, Recovering (bio) Resources for the World, Santiago de Compostela, IWA, 2013.

21. Dinucio, E., Balsari, P., Gioelli, F., Menardo, S., Evaluation of the biogas productivity potential of some Italian agro-industrial biomasses, Bioresour. Technol. 101 (2010) 3780. doi: https://doi.org/10.1016/j.biortech.2009.12.113

22. Naik, S. N., Goud, V. V., Rout, P. K., Dalai, A. K., Production of first and second generation biofuels: A comprehensive review, Renew. Sust. Energ. Rev. 14 (2010) 578 doi: https://doi.org/10.1016/j.rser.2009.10.003

23. URL: http://www.biogasheat.org/hr/poziv-na-zavrsnu-konferenciju-biogasheat-u-zagrebu-27-3-2015/ (11. 4. 2016)

24. URL: http://european-biogas.eu/ (24. 3. 2017)

25. URL: http://www.eurobserv-er.org/category/all-biogas-barometers/ (11. 4. 2016)
26. Dilea, M., Paraschiv, G., Ungureanu, N., Voicu, G., Biris, $S$., Ionescu, M., Biogas, a modern renewable energy in the European context, $2^{\text {nd }}$ International Conference on Thermal Equipment, Renewable Energy and Rural Development, Constanta, Romania, 2013.

27. Harmsen, P. F. H., Huijgen, W. J. J., Bermúdez López, L. M., Bakker, R. R. C., Literature Review of Physical and Chemical Pretreatment Processes for Lignocellulosic Biomass, Energy Research Centre of the Netherlands, 2010.

28. Shahzadi, T., Mehmood, S., Irshad, M., Anwar, Z., Afroz, A., Zeeshan, N., Rashid, U., Sughra, K., Advances in lignocellulosic biotechnology: A brief review on lignocellulosic biomass and cellulases, ABB 5 (2014) 246 doi: https://doi.org/10.4236/abb.2014.53031

29. Zheng, Y., Zhao, J., Xu, F., Li, Y., Pretreatment of lignocellulosic biomass for enhanced biogas production, Progress in Energy and Combustion Science 42 (2014) 35. doi: https://doi.org/10.1016/j.pecs.2014.01.001

30. Taherzadeh, M. J., Karimi, K., Pretreatment of lignocellulosic wastes to improve ethanol and biogas production: A review, Int. J. Mol. Sci. 9 (2008) 1621. doi: https://doi.org/10.3390/ijms9091621

31. Bénes, I., Velić, N., Planinić, M., Šmogrovičová, D., Tišma, $M$., Utilization of pentosans from sugar beet pulp by different white-rot fungi, Int. Proc. Chem. Biol. Environ. Eng. 50 (2013) 94.

32. Monlau, F., Barakat, A., Trably, E., Dumas, C., Steyer, J.-P., Carrère, $H$. ., Lignocellulosic materials into biohydrogen and biomethane: Impact of structural features and pretreatment, Crit. Rev. Env. Sci. Tec. 43 (2013) 260. doi: https://doi.org/10.1080/10643389.2011.604258

33. Antonopoulou, G., Dimitrellos, G., Beobide, A. S., Vayenas, D., Lyberatos, $G$., Chemical pretreatment of sunflower straw biomass: The effect on chemical composition and structural changes, Waste Biomass Valorization 6 (5) (2015) 733.

doi: https://doi.org/10.1007/s12649-015-9388-x

34. Hesami, S. M., Zilouei, H., Karimi, K., Asadinezhad, A., Enhanced biogas production from sunflower stalks using hydrothermal and organosolv pretreatment, Ind. Crop. Prod. 76 (2015) 449. doi: https://doi.org/10.1016/j.indcrop.2015.07.018

35. Liu, Z., Cao, Y., Wang, Z., Ren, H., Amidon, T. E., Lai, Y., The utilization of soybean straw. I. Fiber morphology and chemical characteristics, Bioresources 10 (2) (2015) 2266. doi: https://doi.org/10.15376/biores.10.2.2266-2280

36. Monlau, F., Kaparaju, P., Trably, E., Steyer, J. P., Carrere, $H$., Alkaline pretreatment to enhance one-stage $\mathrm{CH}_{4}$ and two-stage $\mathrm{H}_{2} / \mathrm{CH}_{4}$ production from sunflower stalks: Mass, energy and economical balances, Chem. Eng. J. 260 (2015) 377.

doi: https://doi.org/10.1016/j.cej.2014.08.108

37. Monlau, F., Barakat, A., Steyer, J. P., Carrere, H., Comparison of seven types of thermo-chemical pretreatments on the structural features and anaerobic digestion on sunflower stalks, Bioresour. Technol. 120 (2012) 241. doi: https://doi.org/10.1016/j.biortech.2012.06.040

38. Sharma, S. K., Karla, K. L., Grewal, H. S., Enzymatic saccharification of pretreated sunflower stalks, Biomass Bioenerg. 23 (3) (2002) 237. doi: https://doi.org/10.1016/S0961-9534(02)00050-8

39. Ruiz, E., Cara, C., Manzanares, P., Ballesteros, M., Castro, $E$., Evaluation of steam explosion pre-treatment for enzymatic hydrolysis of sunflower stalks, Enzyme Microb. Tech. 42 (2) (2008) 160. doi: https://doi.org/10.1016/j.enzmictec.2007.09.002 
40. Sambusiti, C., Physical, chemical, and biological pretreatments to enhance biogas production from lignocellulosic substrates, Politecnico di Milano, Italy, Milano, 2012, pp 24.

41. Liew, L. N., Solid-state anaerobic digestion of lignocellulosic biomass for biogas production, The Ohio State University, Columbus, Ohio, 2011, pp 49.

42. Li, Y., Zhu, J., Wan, C., Park, S. Y., Solid-state anaerobic digestion of corn stover for biogas production, ASABE $\mathbf{5 4}$ (4) (2011) 1415. doi: https://doi.org/10.13031/2013.39010

43. Saha, B. C., Hemicellulose bioconversion, J. Ind. Microbiol. Biot. 30 (2003) 279. doi: https://doi.org/10.1007/s10295-003-0049-x

44. Lee, D., Owens, V. N., Boe, A., Jeranyama, P., Composition of Herbaceous Biomass Feedstocks, Report SGINC1-07, North Central Sun Grant Center, South Dakota State University, South Dakota, Brookings, 2007.

45. Saha, B. C., Yoshida, T., Cotta, M. A., Sonomoto, K., Hydrothermal pretreatment and enzymatic saccharification of corn stover for efficient ethanol production, Ind. Crop. Prod. 44 (2013) 367. doi: https://doi.org/10.1016/j.indcrop.2012.11.025

46. Mule, R. S., Barbind, R. P., Baswade, S. W., Samale, D. T., Adangale, S. B., Nutritive value of soybean straw in osmanabadi kids, Vet. World 1 (10) (2008) 314.

47. Perry, T. W., Cecava, M. J., Beef cattle feeding and nutrition, Academic Press Inc., West Lafayette, Indiana, 1995.

48. Ahn, H. K., Sauer, T. J., Richard, T. L., Glanville, T. D., Determination of thermal properties of composting bulking materials, Bioresour. Technol. 100 (2009) 3974. doi: https://doi.org/10.1016/j.biortech.2008.11.056

49. Shen, W., Wang, J., Kong, Q., Guan, J., Cui, J., Liu, Z., Research on analysis model of soybean straw component, IJMUE 10 (6) (2015) 187. doi: https://doi.org/10.14257/ijmue.2015.10.6.19

50. Yang, S., El-Enshasy, H. A., Thongchul, N., Bioprocessing technologies in biorefinery for sustainable production of fuels, chemicals, and polymers, John Wiley \& Sons, Inc., Hoboken, New Jersey, 2013 doi: https://doi.org/10.1002/9781118642047

51. Binder, J. B., Raines, R. T., Fermentable sugars by chemical hydrolysis of biomass, P. Natl. Acad. Sci. USA 170 (10) (2010) 4516. doi: https://doi.org/10.1073/pnas.0912073107

52. Wyman, C. E., Corn Chemistry and Technology, American Association of Cereal Chemists, St. Paul, Minnesota, 2003, pp 723.

53. Templeton, D. W., Sluiter, A. D., Hayward, T. K., Hames, B. $R$., Thomas, S. R., Assessing corn stover composition and sources of variability via NIRS, Cellulose 16 (2009) 621. doi: https://doi.org/10.1007/s10570-009-9325-x

54. Wan, C., Zhou, Y., Li, Y., Liquid hot water and alkaline pretreatment of soybean straw for improving cellulose digestibility, Bioresour. Technol. 102 (2011) 6254 doi: https://doi.org/10.1016/j.biortech.2011.02.075

55. Akpinar, O., Levent, O., Sabanci, S., Uysal, R. S., Sapci, B. Optimization and comparison of dilute acid pretreatment of selected agricultural residues for recovery of xylose, Bioresources 6 (4) (2011) 4103.

56. Ziebell, A. L., Barb, J. G., Sandhu, S., Moyers, B. T., Sykes, R. W., Doeppke, C., Gracom, K. L., Carlile, M., Marek, L. F., Davis, M. F., Knapp, S. J., Burke, J. M., Sunflower as a biofuels crop: An analysis of lignocellulosic chemical properties, Biomass Bioenerg. 59 (2013) 208 doi: https://doi.org/10.1016/j.biombioe.2013.06.009
57. Jørgensen, H., Kristensen, J. B., Felby, C., Enzymatic conversion of lignocellulose into fermentable sugars: challenges and opportunities, Biofuel Bioprod. Bior. 1 (2007) 119. doi: https://doi.org/10.1002/bbb.4

58. Kumar, P., Barrett, D. M., Delwiche, M. J., Stroeve, P., Methods for pretreatment of lignocellulosic biomass for efficient hydrolysis and biofuel production, Ind. Eng. Chem. Res. 48 (8) (2009) 3713. doi: https://doi.org/10.1021/ie801542g

59. Deepanraj, B., Sivasubramanian, V., Jayaraj, S., Enhancement of biogas production by pretreatment: A review, $4^{\text {th }}$ International Conference on Advances in Energy Research, Indian Institute of Technology Bombay, Mumbai, India, 2013.

60. Kratky, L., Jirout, T., Biomass size reduction machines for enhancing biogas production, Chemical Engineering and Technology 34 (3) (2011) 391. doi: https://doi.org/10.1002/ceat.201000357

61. Balsari, P., Menardo, S., Airoldi, G., Effect of physical and thermal pre-treatments on biogas yield of some agricultural by-products, International Congress Progress in Biogas II, Stuttgart-Hohenheim, Germany, 2011.

62. Sun, Y., Cheng, J., Hydrolysis of lignocellulosic materials for ethanol production: A review, Bioresource Technology 83 (2002) 1

doi: https://doi.org/10.1016/S0960-8524(01)00212-7

63. Sharma, S. K., Mishra, I. M., Sharma, M. P., Saini, J. S., Effect of particle size on biogas generation from biomass residues, Biomass 17 (1988) 251. doi: https://doi.org/10.1016/0144-4565(88)90107-2

64. Zheng, M., Mosier, N. S., Huang, C. P., Sherman, D. M., Ladisch, M. R., Microscopic examination of changes of plant cell structure in corn stover due to hot water pretreatment and enzymatic hydrolysis, Biotechnol. Bioeng. 97 (2) (2007) 265. doi: https://doi.org/10.1002/bit.21298

65. Xiao, X., Zhang, R., He, Y., Li, Y., Feng, L., Chen, C., Liu, $G$., Influence of particle size and alkaline pretreatment on the anaerobic digestion of corn stover, Bioresources 8 (4) (2013) 5850 . doi: https://doi.org/10.15376/biores.8.4.5850-5860

66. Schell, D. J., Harwood, C., Milling of lignocellulosic biomass, results of pilot-scale testing, Appl. Biochem. Biotech. 45/46 (1994) 159. doi: https://doi.org/10.1007/BF02941795

67. Menardo, S., Airoldi, G., Balsari, P., The effect of particle size and thermal pre-treatment on the methane yield of four agricultural by-products, Bioresour. Technol. 104 (2012) 708. doi: https://doi.org/10.1016/j.biortech.2011.10.061

68. Mshandete, A., Björnsson, L., Kivaisi, A. K., Rubindamayugi, M. S. T., Mattiasson, B., Effect of particle size on biogas yield from sisal fibre waste, Renewable Energy 31 (2006) 2385 .

doi: https://doi.org/10.1016/j.renene.2005.10.015

69. Liu, Z.-H., Qin, L., Pang, F., Jin, M.-J., Li, B.-Z., Kang, Y., Dale, B. E., Yuan, Y.-J., Effects of biomass particle size on steam explosion pretreatment performance for improving the enzyme digestibility of corn stover, Industrial Crops and Products 44 (2013) 176. doi: https://doi.org/10.1016/j.indcrop.2012.11.009

70. Mtui, G. Y. S., Recent advances in pretreatment of lignocellulosic wastes and production of value added products, Afr. J. Biotechnol. 8 (8) (2009) 1398. 
71. Bondesson, P., Galbe, M., Zacchi, G., Ethanol and biogas production after steam pretreatment of corn stover with or without the addition of sulphuric acid, Biotechnol. Biofuels 6 (1) (2013) 1.

doi: https://doi.org/10.1186/1754-6834-6-11

72. Mosier, N., Hendrickson, R., Ho, N., Sedlak, M., Ladisch, $M$. R., Optimization of $\mathrm{pH}$ controlled liquid hot water pretreatment of corn stover, Bioresour. Technol. 96 (18) (2005) 1986.

doi: https://doi.org/10.1016/j.biortech.2005.01.013

73. Chandra, R., Takeuchi, H., Hasegawa, T., Kumar, R., Improving biodegradability and biogas production of wheat straw substrates using sodium hydroxide and hydrothermal pretreatments, Energy 43 (1) (2012) 273. doi: https://doi.org/10.1016/j.energy.2012.04.029

74. Montgomery, L. F. R., Bochmann, G., Pretreatment of feedstock for enhanced biogas production, IEA Bioenergy, 2014.

75. Hjorth, M., Gränitz, K., Adamsen, A. P. S., Møller, H. B., Extrusion as a pretreatment to increase biogas production, Bioresour. Technol. 102 (2011) 4989. doi: https://doi.org/10.1016/j.biortech.2010.11.128

76. Beszédes, S., Ábel, M., Szabó, G., Hodúr, C., László, Z., Enhanced enzymatic saccharification of agri-food solid wastes by microwave pretreatment, Annals of the Faculty of Engineering Hunedoara 9 (3) (2011) 453.

77. Singh, A., Tuteja, S., Singh, N., Bishnoi, N. R., Enhanced saccharification of rice straw and hull by microwave-alkali pretreatment and lignocellulytic enzyme production, Bioresour. Technol. 102 (2011) 1773. doi: https://doi.org/10.1016/j.biortech.2010.08.113

78. Singh, R., Tiwari, S., Srivastava, M., Mina, U., Effect of combination of microwave and hydrogen peroxide $\left(\mathrm{H}_{2} \mathrm{O}_{2}\right)$ pretreatment on enzymatic saccharification of rice straw, IJEEM 4 (5) (2013) 529.

79. $\mathrm{Oz}$, N. A., Yarimtepe, C. C., Ultrasound assisted biogas production from landfill leachate, Waste Manage. 34 (2014) 1165.

doi: https://doi.org/10.1016/j.wasman.2014.03.003

80. Liqian, $W$., Different pretreatments to enhance biogas production; a comparison of thermal, chemical and ultrasound methods, Halmstad University, Halmstad, Sweden, 2011.

81. Lebovka, N. I., Bazhal, M. I., Vorobiev, E. I., Simulation and experimental investigation of food material breakage using pulsed electric field treatment, J. Food Eng. 44 (2000) 213. doi: https://doi.org/10.1016/S0260-8774(00)00029-7

82. Fincan, M., Dejmek, $P$., In situ visualization of the effect of a pulsed electric field on plant tissue, J. Food Eng. 55 (2002) 223 doi: https://doi.org/10.1016/S0260-8774(02)00079-1

83. Asavasanti, S., Ersus, S., Ristenpart, W., Stroeve, P., Barrett, D. M., Critical electric field strengths of onion tissues treated by pulsed electric fields, J. Food Sci. 75 (7) (2010) 433.

doi: https://doi.org/10.1111/j.1750-3841.2010.01768.x

84. Ersus S., Oztop M. H., McCarthy, M. J., Barrett, M., Disintegration efficiency of pulsed electric field induced effects on onion (Allium cepa L.) tissues as a function of pulse protocol and determination of cell integrity by ${ }^{1} \mathrm{H}-\mathrm{NMR}$ relaxometry, J. Food Sci. 75 (7) (2010) 444. doi: https://doi.org/10.1111/j.1750-3841.2010.01769.x

85. Zderic, A., Zondervan, E., Meuldijk, J., Breakage of cellular tissue by pulsed electric field: extraction of polyphenols from fresh tea leaves, CET 32 (2013) 1795.
86. Lindmark, J., Developing the anaerobic digestion process through technology integration, Mälardalen University, Västerås, Sweden, 2014.

87. Saritha, M., Arora, A., Lata, Biological pretreatment of lignocellulosic substrates for enhanced delignification and enzymatic digestibility, Indian J. Microbiol. 52 (2) (2012) 122 .

doi: https://doi.org/10.1007/s12088-011-0199-x

88. Čater, M., Zorec, M., Logar, R. M., Methods for improving anaerobic lignocellulosic substrates degradation for enhanced biogas production, Springer Science Reviews 2 (2014) 51. doi: https://doi.org/10.1007/s40362-014-0019-x

89. Sigoillot, J., Berrin, J., Bey, M., Lesage-Meessen, L., Levasseur, A., Lomascolo, A., Record, E., Uzan-Boukhris, E., Advances in Botanical Research, Lignins: Biosynthesis, Biodegradation and bioengineering, Elsevier, USA, 2012, pp 263-308.

doi: https://doi.org/10.1016/B978-0-12-416023-1.00008-2

90. Pointing, S. B., Feasibility of bioremediation by white-rot fungi, Appl. Microbiol. Biot. 57 (2001) 20. doi: https://doi.org/10.1007/s002530100745

91. Bajpai, P., Pretreatment of lignocellulosic biomass for biofuel production, Springer, Singapore Pte Ltd., 2016.

92. Planinić, M., Zelić, B., Čubel, I., Bucić-Kojić, A., Tišma, M., Corn forage biological pretreatment by Trametes versicolor in a tray bioreactor, Waste Manage. Res. 34 (2016) 802 . doi: https://doi.org/10.1177/0734242X16654979

93. Tišma, M., Sudar, M., Vasić-Rački, Đ., Zelić, B., Mathematical model for Trametes versicolor growth in submerged cultivation, Bioproc. Biosyst. Eng. 33 (2010) 749. doi: https://doi.org/10.1007/s00449-009-0398-6

94. Tišma, M., Žnidaršič-Plazl, P., Vasić-Rački, Đ., Zelić, B., Optimization of laccase production by Trametes versicolor cultivated on industrial waste, Appl. Biochem. Biotech. 166 (2012) 36 doi: https://doi.org/10.1007/s12010-011-9401-1

95. Phutela, U. G., Sahni, N., Sooch, S. S., Fungal degradation of paddy straw for enhancing biogas production, Indian $\mathrm{J}$. Sci. Technol. 4 (6) (2011) 660.

96. Liu, S., Li, X., Wu, S., He, J., Pang, C., Deng, Y., Dong, R., Fungal pretreatment by Phanerochaete chrysosporium for enhancement of biogas production from corn stover silage, Appl. Biochem. Biotech. 174 (5) (2014) 1907. doi: https://doi.org/10.1007/s12010-014-1185-7

97. Liu, S., Wu, S., Zhang, W., Pang, C., Deng, Y., Dong, R., Effect of white rot fungi pretreatment on methane production from anaerobic digestion of corn stover, Transactions of the Chinese Society for Agricultural Machinery 44 (2013) 124

98. Müller, H. W., Trösch, W., Screening of white-rot fungi for biological pretreatment of wheat straw for biogas production, Appl. Microbiol. Biot. 24 (1986) 180. doi: https://doi.org/10.1007/BF00938793

99. Lechner, B. E., Papinutti, V. L., Production of lignocellulosic enzymes during growth and fruiting of the edible fungus Lentinus tigrinus on wheat straw, Process Biochem. 41 (2006) 594. doi: https://doi.org/10.1016/j.procbio.2005.08.004

100. Vasmara, C., Cianchetta, S., Marchetti, R., Galletti, S., Biogas production from wheat straw pre-treated with ligninolytic fungi and co-digestion with pig slurry, Environ. Eng. Manag. J. 14 (7) (2015) 1751. 
101. Amirta, R., Tanabe, T., Watanabe, T., Honda, Y., Kuwaha$\mathrm{ra}, \mathrm{M}$., Watanabe, T., Methane fermentation of Japanese cedar wood pretreated with a white rot fungus, Ceriporiopsis subvermispora, J. Biotechnol. 123 (2006) 71. doi: https://doi.org/10.1016/j.jbiotec.2005.10.004

102. Ghosh, A., Bhattacharyya, B. C., Biomethanation of white rotted and brown rotted rice straw, Bioprocess Eng. 20 (1999) 297. doi: https://doi.org/10.1007/s004490050594

103. Taniguchi, M., Suzuki, H., Watanabe, D., Sakai, K., Hoshino, K., Tanaka, T., Evaluation of pretreatment with Pleurotus ostreatus for enzymatic hydrolysis of rice straw, J. Biosci. Bioeng. 100 (6) (2005) 637. doi: https://doi.org/10.1263/jbb.100.637

104. Kangrang, S., Cheenkachorn, K., Rattanaporn, K., Sriariyanun, $M$., Analysis of a lignocellulose degrading microbial consortium to enhance the anaerobic digestion of rice straws, International Journal of Biological, Biomolecular, Agricultural, Food and Biotechnological Engineering 9 (5) (2015) 471.

105. Yan, L., Gao, Y., Wang, Y., Liu, Q., Sun, Z., Fu, B., Wen, X., Cui, $Z$., Wang, $W$., Diversity of a mesophilic lignocellulolytic microbial consortium which is useful for enhancement of biogas production, Bioresour. Technol. 111 (2012) 49. doi: https://doi.org/10.1016/j.biortech.2012.01.173

106. Spajić, R., Comparison of liquid feeding components in biogas production, University of Josip Juraj Strossmayer in Osijek, Faculty of Agriculture in Osijek, Osijek, 2010.

107. Boussaid, A., Saddler, J. N., Adsorption and activity of profiles of cellulases during the hydrolysis of two Douglas fir pulps, Enzyme Microb. Tech. 24 (3-4) (1999) 138. doi: https://doi.org/10.1016/S0141-0229(98)00096-9

108. Gao, D., Uppugundla, N., Chundawat, S. P. S., Yu, X., Hermanson, S., Gowda, K., Brumm, P., Mead, D., Balan, $V$., Dale, B. E., Hemicellulases and auxiliary enzymes for improved conversion of lignocellulosic biomass to monosaccharides, Biotechnol. Biofuels 4 (1) (2011) 1. doi: https://doi.org/10.1186/1754-6834-4-5
109. Liu, Z., Qin, L., Pang, F., Jin, M., Li, B., Kang, Y., Effects of biomass particle size on steam explosion pretreatment performance for improving the enzyme digestibility of corn stover, Ind. Crop. Prod. 44 (2013) 176. doi: https://doi.org/10.1016/j.indcrop.2012.11.009

110. Kakuk, B., Strang, O., Ács, N., Kovács, E., Rákhely, G., Kovács, K. L., Bagi, Z., The impact of bacterial pretreatment on corn stover for biogas production, Buletinul AGIR 1 (2013) 9.

111. Fang, W., Weisheng, N., Andong, Z., Weiming, Y., Enhanced anaerobic digestion of corn stover by thermos-chemical pretreatment, IJABE 8 (1) (2015) 84.

112. Lynch, J. P., O'Kiely, P. O., Murphy, R., Doyle, E. M., Changes in chemical composition and digestibility of three maize stover components digested by white-rot fungi, J. Anim. Physiol. Anim. Nutr. 98 (2014) 731. doi: https://doi.org/10.1111/jpn.12131

113. Brown, D., Shi, J., Li, Y., Comparison of solid-state to liquid anaerobic digestion of lignocellulosic feedstocks for biogas production, Bioresour. Technol. 124 (2012) 379. doi: https://doi.org/10.1016/j.biortech.2012.08.051

114. Liu, S., Wu, S., Pang, C., Li, W., Dong, R., Microbial pretreatment of corn stovers by solid-state cultivation of Phanerochaete chrysosporium for biogas production, Appl. Biochem. Biotech. 172 (2014) 1365. doi: https://doi.org/10.1007/s12010-013-0604-5

115. Gontupil, J., Liu, Z., Win, D., Cheng, J. J., Anaerobic co-digestion of swine manure and corn stover with additional enzymes for enhancing biogas production, Institute of Biological Engineers (IBE) Annual Conference, At Raleigh, North Carolina, USA, 2013.

116. Schroyen, M., Vervaeren, H., Van Hulle, S. W. H., Raes, K., Impact of enzymatic pretreatment on corn stover degradation and biogas production, Bioresour. Technol. 173 (2014) 59.

doi: https://doi.org/10.1016/j.biortech.2014.09.030 